\title{
Bifidobacterium thermacidophilum sp. nov., isolated from an anaerobic digester
}

\author{
Xiuzhu Dong, Yuhua Xin, Wenying Jian, Xiaoli Liu and Daiwen Ling
}

China General

Microorganisms Culture Collection Centre, Institute of Microbiology, Chinese Academy of Sciences, Beijing 100080, PR China
Author for correspondence: Xiuzhu Dong. Tel: +86 10625 58320. Fax: +861062560912. e-mail: dongxz@sun.im.ac.cn
Keywords: anaerobic digester, Bifidobacterium thermacidophilum, DNA relatedness, phylogeny

\section{INTRODUCTION}

Since Bifidobacterium was first described by Tissier in 1899, 32 species have been assigned to this genus (Scardovi, 1986; Biavati et al., 1991; Biavati \& Mattarelli, 1991; Watabe et al., 1983; Crociani et al., 1996; Meile et al., 1997; Lauer, 1990). The bacteria in this group were mainly isolated from the intestines of humans and animals. They were believed to be predominantly a constituent of the intestinal flora. Thus far, no Bifidobacterium strains have been found in clinical specimens, except for three species found in human dental caries. In recent years, these bacteria have been used as probiotics to suppress intestinal pathogens. In addition, bifidobacteria have also been found in other anoxic environments, such as sewage. Recently, Bifidobacterium lactis was isolated from fermented milk (Meile et al., 1997).

Though some of the species of Bifidobacterium showed phenotypic and genetic heterogeneity (Chevalier et al., 1990), the validity of most species was confirmed by $16 \mathrm{~S}$ rRNA sequence homology analyses (LeblondBourget et al., 1996; Stackebrandt \& Goebel, 1994). Furthermore, most members of the genus Bifido-

The GenBank/EMBL/DDBJ accession number for the $16 \mathrm{~S}$ rDNA sequence of strain 36 reported in this paper is AB016246. bacterium were demonstrated, by DNA-DNA relatedness determinations (Lauer \& Kandler, 1983, Stackebrandt \& Goebel, 1994), to be the well-established species.

In a previous study in our laboratory, 42 strains of bifidobacteria were isolated from human and animal faeces and from an anaerobic digester for the treatment of waste water from a bean-curd farm in Beijing (Ling et al., 1996). The assignment of strains to the genus Bifidobacterium was done on the basis of the following diagnostic characteristics: they were Gram-positive, pleomorphic, irregular, non-spore-forming rods; they showed anaerobic growth; they were non-motile and catalase-negative; and they produced acetic and lactic acid as the main products of glucose fermentation and did not produce gas. A total of six phenotypic clusters were defined from numerical analysis based on 75 features. Strains in cluster E, all of which were isolated from the waste water of the bean-curd farm, clustered distantly from other strains, with a quite low $S_{\mathrm{M}}$ value $(<60 \%)$. In addition, this group of strains could not be identified as one of the existing Bifidobacterium species according to the conventional classification. To clarify their taxonomic position, the DNA-DNA relatedness between one of the new isolates and existing members of the genus Bifidobacterium was determined. The results revealed a new species of the 
genus Bifidobacterium. Its phylogenetic relationship with other species was also analysed according to $16 \mathrm{~S}$ rDNA sequence homologies.

\section{METHODS}

Bacterial strains. All of the bifidobacterial strains used in this study are listed in Table 1. The reference strains were kindly provided by the Japan Collection of Microorganisms (JCM) and the German Collection of Microorganisms and Cell Cultures (DSMZ), respectively. The strains from our collection were isolated by the Hungate anaerobic roll-tube technique and were routinely grown in tryptone peptone yeast extract glucose (TPYG) medium (Scardovi, 1986). The media were prepared in glass tubes sealed with butyl rubber stoppers and screw caps. The gas phase was $\mathrm{N}_{2}$. After inoculation, tubes were incubated at $37^{\circ} \mathrm{C}$. The cultures for the tests below were all cultivated anaerobically unless otherwise indicated.

Characterization of the strains. Fructose-6-phosphate phosphoketolase activity in cell extract was assayed as described previously (Scardovi, 1986).

End products from glucose fermentation were detected by GC (GC-7AG; Shimadzu). Bacterial strains were inoculated in TPYG media as well as in tryptone peptone yeast extract (TPY) media without glucose (as the control). After $48 \mathrm{~h}$ growth, the products were analysed. The acids produced during glucose fermentation and the ratio of acetic acid to

Table 1. DNA homologies between Bifidobacterium thermacidophilum $36^{\top}$ and existing species of the genus Bifidobacterium

\begin{tabular}{|c|c|}
\hline Bifidobacterium species & $\begin{array}{c}\text { Reassociation with DNA of } \\
\text { B. thermacidophilum } 36^{\mathrm{T}} \\
(\%)\end{array}$ \\
\hline B. thermacidophilum $36^{\mathrm{T}}$ (AS $1.2282^{\mathrm{T}}$ ) & $100 \cdot 0^{*}$ \\
\hline B. thermacidophilum 35 & $87 \cdot 0,92 \cdot 1,94 \cdot 0 *$ \\
\hline B. thermacidophilum 37 & $92 \cdot 5,94 \cdot 3,118 \cdot 6^{*}$ \\
\hline B. adolescentis JCM $1275^{\mathrm{T}}$ (ATCC $15703^{\mathrm{T}}$ ) & $17 \cdot 9$ \\
\hline B. angulatum JCM $7096^{\mathrm{T}}\left(\right.$ ATCC $\left.27535^{\mathrm{T}}\right)$ & $38 \cdot 7$ \\
\hline B. animalis JCM $1190^{\mathrm{T}}\left(\mathrm{ATCC} 25527^{\mathrm{T}}\right)$ & $28 \cdot 5$ \\
\hline B. asteroides JCM $8230^{\mathrm{T}}$ (ATCC $25910^{\mathrm{T}}$ ) & $29 \cdot 5$ \\
\hline B. bifidum JCM $1255^{\mathrm{T}}\left(\mathrm{ATCC} 29521^{\mathrm{T}}\right)$ & $34 \cdot 7$ \\
\hline B. boum JCM $1211^{\mathrm{T}}\left(\mathrm{ATCC} 27917^{\mathrm{T}}\right)$ & $34 \cdot 3$ \\
\hline B. breve JCM $1192^{\mathrm{T}}\left(\mathrm{ATCC} 15700^{\mathrm{T}}\right)$ & $9 \cdot 0$ \\
\hline B. catenulatum JCM $1194^{\mathrm{T}}$ (ATCC 27539 $)$ & $22 \cdot 9$ \\
\hline B. choerinum JCM $1212^{\mathrm{T}}\left(\mathrm{ATCC} 27686^{\mathrm{T}}\right)$ & $24 \cdot 6$ \\
\hline B. coryneforme JCM 5819 $\left(\mathrm{ATCC} 25911^{\mathrm{T}}\right)$ & $24 \cdot 0$ \\
\hline B. cuniculi JCM $1213^{\mathrm{T}}\left(\mathrm{ATCC} 27916^{\mathrm{T}}\right.$ ) & $41 \cdot 4$ \\
\hline B. dentium JCM $1195^{\mathrm{T}}\left(\mathrm{ATCC} 27534^{\mathrm{T}}\right.$ ) & $42 \cdot 0$ \\
\hline B. denticolens DSM $10105^{\mathrm{T}}$ & $47 \cdot 3$ \\
\hline B. gallicum JCM $8224^{\mathrm{T}}\left(\mathrm{ATCC} 49850^{\mathrm{T}}\right)$ & $26 \cdot 3$ \\
\hline B. gallinarum JCM $6291^{\mathrm{T}}\left(\mathrm{ATCC} 33777^{\mathrm{T}}\right)$ & $34 \cdot 3$ \\
\hline B. globosum JCM 5820 (ATCC 25865 $)$ & $36 \cdot 8$ \\
\hline B. indicum JCM $1302^{\mathrm{T}}\left(\mathrm{ATCC} 25912^{\mathrm{T}}\right)$ & $31 \cdot 6$ \\
\hline B. inopinatum DSM $10107^{\mathrm{T}}$ & 0 \\
\hline B. infantis JCM $1222^{\mathrm{T}}\left(\mathrm{ATCC} 15697^{\mathrm{T}}\right.$ ) & $26 \cdot 0$ \\
\hline B. lactis DSM $10140^{\mathrm{T}}$ & $34 \cdot 6$ \\
\hline B. longum JCM 1217 $\left(\right.$ ATCC $\left.15707^{\mathrm{T}}\right)$ & $27 \cdot 7$ \\
\hline B. magnum JCM $1218^{\mathrm{T}}\left(\mathrm{ATCC} 27540^{\mathrm{T}}\right)$ & 0 \\
\hline B. merycicum JCM $8219^{\mathrm{T}}\left(\right.$ ATCC $\left.49391^{\mathrm{T}}\right)$ & $25 \cdot 0$ \\
\hline B. minimum JCM $5821^{\mathrm{T}}\left(\mathrm{ATCC} 27538^{\mathrm{T}}\right)$ & $22 \cdot 9$ \\
\hline B. pseudocatenulatum JCM $1200^{\mathrm{T}}$ (ATCC $27910^{\mathrm{T}}$ ) & $30 \cdot 9$ \\
\hline B. pseudolongum JCM $1205^{\mathrm{T}}$ (ATCC $25526^{\mathrm{T}}$ ) & $30 \cdot 5$ \\
\hline B. pullorum JCM $1214^{\mathrm{T}}$ (ATCC $27685^{\mathrm{T}}$ ) & $24 \cdot 5$ \\
\hline B. ruminantium JCM $8222^{\mathrm{T}}$ (ATCC $49390^{\mathrm{T}}$ ) & $31 \cdot 6$ \\
\hline B. saeculare JCM $8223^{\mathrm{T}}$ (ATCC $49392^{\mathrm{T}}$ ) & $27 \cdot 8$ \\
\hline B. subtile JCM $5822^{\mathrm{T}}\left(\mathrm{ATCC} 27535^{\mathrm{T}}\right)$ & $19 \cdot 3$ \\
\hline B. suis $\mathrm{JCM} 1269^{\mathrm{T}}\left(\mathrm{ATCC} 27533^{\mathrm{T}}\right)$ & $3 \cdot 0$ \\
\hline B. thermophilum JCM $1207^{\mathrm{T}}$ (ATCC $25525^{\mathrm{T}}$ ) & $58 \cdot 9$ \\
\hline
\end{tabular}

* DNA reassociation rates $(\%)$ among the three strains of $B$. thermacidophilum refer to the determinations using three different batches of DNA. 
lactic acid were measured according to the methods described by Holdeman et al. (1977).

The determination of sugar-fermentation patterns was achieved as follows. Sugars (final concentration 1\%) sterilized by filtration were added aseptically to the autoclaved TPY broth ( $\mathrm{pH} 7 \cdot 0-7 \cdot 2)$ without substrate. The TPY/sugar broths were inoculated with the different strains and cultivated at $37{ }^{\circ} \mathrm{C}$ for $48 \mathrm{~h}$ or longer, and the decrease in the $\mathrm{pH}$ value was followed by using bromothymol blue $(0.04 \%)$ and methyl red $(0.02 \%)$ as $\mathrm{pH}$ indicators. The temperature profiles were determined using a water bath with a temperature gradient. Initial $\mathrm{pH}$ values and the $\mathrm{NaCl}$ concentrations of the media were obtained by adding $\mathrm{HCl}$ $(0 \cdot 2 \mathrm{M})$ and the required amount of $\mathrm{NaCl}$ to TPYG broth, respectively. Growth was measured using a spectrophotometer at a wavelength of $600 \mathrm{~nm}$ after cultivation at $37^{\circ} \mathrm{C}$ for $24 \mathrm{~h}$ to 1 week. All of the tests were performed in duplicate.

DNA extraction. The chromosomal DNA was extracted using a modified version of the method of Marmur (1961). As the cell walls of bifidobacteria were hard to lyse with lysozyme and SDS, $0.5 \mathrm{mg}$ penicillin $\mathrm{G} \mathrm{ml}^{-1}$ culture was added to the cultures at late exponential phase to assist cell breakage. The cultures were incubated for another 16-20 h. To obtain higher yields of DNA, protease $\mathrm{K}\left(100 \mu \mathrm{g} \mathrm{ml}^{-1}\right.$, $37^{\circ} \mathrm{C}$ for $1.5-2 \mathrm{~h}$ ) was used instead of phenol, to remove the contaminated protein.

Determination of $\mathbf{G}+\mathbf{C}$ content of DNA and DNA relatedness analysis. The $\mathrm{G}+\mathrm{C}$ content of the DNA was determined by thermal denaturation (Marmur \& Doty, 1962). The DNA from Escherichia coli K-12 was used as reference for thermal melting profile $\left(T_{\mathrm{m}}\right)$ determinations. DNA-DNA relatedness between the new isolates and all the reference strains was determined on the basis of the DNA-DNA liquid reassociation rate, as described by De Ley et al. (1970). The purity and concentration of each DNA preparation in $0 \cdot 1 \times$ SSC (saline sodium citrate buffer) were determined by measuring the optical density at $260 \mathrm{~nm}$. The amount of DNA used to determine the reassociation rate was approximately $75-80 \mu \mathrm{g} \mathrm{ml}^{-1}$. After the DNA was sheared to approximately $2.5 \times 10^{6} \mathrm{Da}$ by passage through a syringe with a narrow needle (No. 5), the preparation buffer was adjusted to $2 \times \mathrm{SSC}$ to determine the DNA-DNA reassociation rate $\left(\mathrm{v}^{\prime}\right)$. The determinations were all performed at $73{ }^{\circ} \mathrm{C}$ using a 752 Spectrophotometer with a thermometer controller (Shanghai 3rd Analytic Factory) and the renaturation was followed for $30 \mathrm{~min}$. Normally, three batches of DNA per strain were used; only v' values of $\geqslant 3.0 \times 10^{-3} \mathrm{~min}^{-1}$ for self-renaturation were used for DNA-DNA relatedness analysis.

Amplification and cloning of 165 rDNA. Chromosomal DNA prepared as described above was used as the template for PCR amplification; the two primers, 27f (5'-AGAGTTTGATCC/ATGGCTCAG-3') and 1541R (5'-AAGGAGGTGATCCAGCC-3'), were complementary to positions 8-27 and 1525-1541 of 16S rDNA, respectively. Each PCR mixture $(50 \mu \mathrm{l})$ contained the following: approximately $300 \mathrm{ng}$ DNA template; $100 \mu \mathrm{mol}$ each of dATP, dCTP, dGTP and dTTP; $2.5 \mathrm{mM} \mathrm{Mg}^{2+}$; 40 pmol each of the two primers; and 2.5 U Taq DNA polymerase. The following thermal cycling conditions were used: initial denaturing of DNA template at $94{ }^{\circ} \mathrm{C}$ for $5 \mathrm{~min}$ followed by 30 cycles comprising (1) denaturation at $94{ }^{\circ} \mathrm{C}$ for $1 \mathrm{~min}$, (2) annealing at $52^{\circ} \mathrm{C}$ for $1 \mathrm{~min}$ and (3) elongation at $72{ }^{\circ} \mathrm{C}$ for $3 \mathrm{~min}$. When the 30 cycles were complete, the reaction mixture was maintained at $72{ }^{\circ} \mathrm{C}$ for $2-3 \mathrm{~h}$. The PCR amplification was performed with a Thermolyne Amplitron I (Barnstead Thermolyne Corporation).

PCR products were purified by agarose gel electrophoresis and electroelution, as described previously (Sambrook et al., 1989), and then ligated to a plasmid pSK-T vector as described by Harrison et al. (1994). The recombinant plasmids with the 16S rDNA insertion were transformed into E. coli $\mathrm{DH} 5 \alpha$.

$16 \mathrm{~S}$ rDNA sequencing. Plasmid pSK-T containing the $16 \mathrm{~S}$ rDNA fragment was extracted and purified by polyethylene glycol precipitation according to the method described previously (Sambrook et al., 1989). Nucleotide sequencing was performed using the Sanger dideoxynucleotide chaintermination method. The complete $16 \mathrm{~S}$ rDNA sequence was determined by using a Dye Terminator Cycle-sequencing Ready Reaction kit (Perkin Elmer). Sequencing was performed with Applied Biosystems 373A-18 equipment. The following oligonucleotides were used as the sequencing primers: the T7 promoter (5'-TAATACGACTCACTATAGGG-3'), the T3 promoter (5'-ATTAACCCTCACTAAAGGGA-3'), 704F (5'-GTAACGGTGGAATGTGTAGA$\left.3^{\prime}\right)$ and $765 \mathrm{R}\left(5^{\prime}-\mathrm{CCTGTTCGCTCCCCACGCTT}-3^{\prime}\right)$. The latter two were complementary to positions 685-704 and 765-784 of the 16S rDNA, respectively.

Analysis of sequence data and phylogenetic tree construction. The $16 \mathrm{~S}$ rDNA sequence determined and those of the reference strains obtained from EMBL/GenBank/DDBJ were aligned by CLUSTAL W software (version 1.5) and the similarities were calculated and converted to a distance matrix with the Jukes-Cantor coefficient by the DNADIST program (PHYLIP, version 3.5; Felsenstein, 1993). A dendrogram was produced by the Fitch method (PHYLIP, version 3.5 ) and the topology of the trees was evaluated by bootstrap analysis of the sequence data with the SEQUENCEBOOTS program (PHYLIP version 3.5).

\section{RESULTS AND DISCUSSION}

The members of the new group of Bifidobacterium strains in this study produced acetic and lactic acid in a molar ratio of 2.46-2.72:1 during glucose fermentation. Cells contained fructose-6-phosphate phosphoketolase activities when growing in TPYG broth. Furthermore, their chromosomal DNA, when used as templates for a PCR reaction, as described by Kaufmann et al. (1997), allowed a Bifidobacterium genus-specific $16 \mathrm{~S}$ rDNA fragment $(1.35 \mathrm{~kb})$ to be amplified (data not shown). Thus, their membership of the genus Bifidobacterium was further confirmed by these analyses, as well as by the characteristics published previously (Ling et al., 1996).

\section{Morphology}

Cells were pleomorphic, rod-, club- or ' $\mathrm{V}$ '-shaped when grown in TPYG media, and $0.5 \times 1.5-2.5 \mu \mathrm{m}$ in size in $24 \mathrm{~h}$ cultures (Fig. 1). The cell wall showed typical Gram-positive staining. Although aggregated cell clumps were formed in liquid cultures, cells were readily dispersed by shaking. Colonies on TPYG agar were convex, entire, white and $2 \mathrm{~mm}$ in diameter after $24 \mathrm{~h}$ cultivation. 


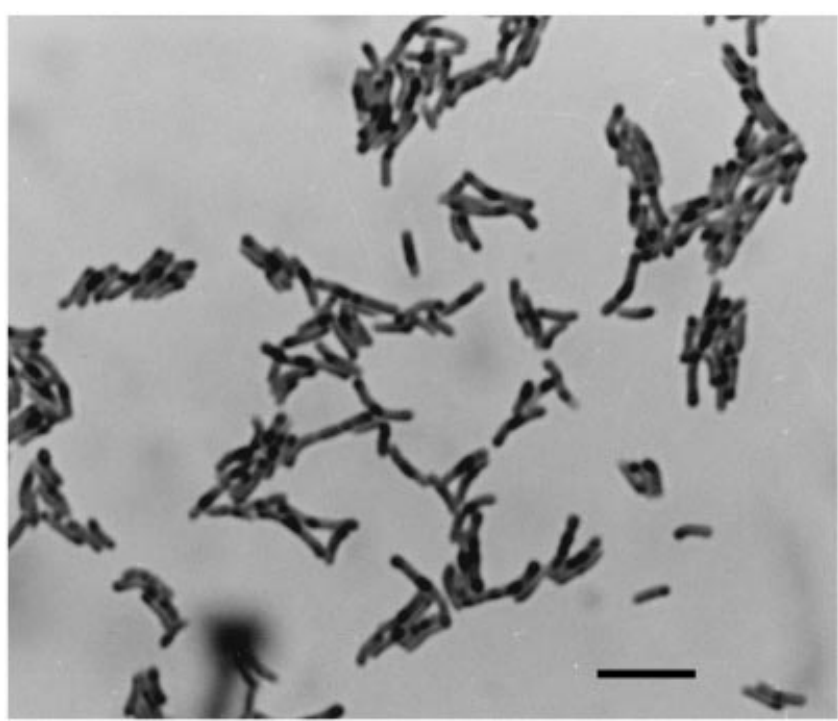

Fig. 1. Micrograph of Bifidobacterium thermacidophilum sp. nov. AS $1.2282^{\top}$ grown on a TYPG slant for $18 \mathrm{~h}$. Bar, $5 \mu \mathrm{M}$.

\section{Physiological features}

The strains shared the common characteristics of Bifidobacterium species, except for the following features. All three strains grew in media with an initial
$\mathrm{pH}$ of 4.0 and at temperatures up to $48 \cdot 5^{\circ} \mathrm{C}$ (strains 36 and 37 even grew at $49 \cdot 5^{\circ} \mathrm{C}$ ). Bifidobacterium thermophilum $\mathrm{JCM} 1207^{\mathrm{T}}$ grew quite poorly at $48.5{ }^{\circ} \mathrm{C}$ and did not grow at all at $49 \cdot 5^{\circ} \mathrm{C}$. Bifidobacterium boum JCM $1211^{\mathrm{T}}$ grew at an even lower temperature $\left(\leqslant 45^{\circ} \mathrm{C}\right)$ and at a more alkaline $\mathrm{pH}(\geqslant 5 \cdot 0)$ (Scardovi et al., 1979). All of the strains grew very well in a medium containing $2.0 \%$ but not $2.5 \%(\mathrm{w} / \mathrm{v}) \mathrm{NaCl}$.

Table 2 shows the carbohydrate fermentation by the three strains of the new species. Two out of the three strains did not ferment lactose but fermented some pentoses and oligo- or polysaccharides such as raffinose, melezitose and starch. These characteristics were rarely shared with most of the other Bifidobacterium species.

\section{$\mathbf{G}+\mathbf{C}$ content of the DNA}

The $\mathrm{G}+\mathrm{C}$ content of the DNA of the new species was determined to be $56 \cdot 85 \pm 2.05 \mathrm{~mol} \%$ and that of the type strain, AS $1.2282^{\mathrm{T}}$, was $57 \cdot 7 \mathrm{~mol} \%$.

\section{DNA-DNA relatedness}

DNA-DNA relatedness was determined using DNADNA liquid reassociation rates. The levels of DNADNA relatedness among the new strains as well as those between the new species and all of the existing Bifidobacterium species are listed in Table 1. The high

Table 2. Differential characteristics of Bifidobacterium thermacidophilum sp. nov., Bifidobacterium thermophilum and Bifidobacterium boum

+ , Positive reaction; - , negative reaction; w, weak reaction; $\mathrm{d}$, reaction variable among strains. All strains were positive for acid from D-fructose, D-galactose, melibiose, sucrose and raffinose.

All strains were negative for acid from D-mannose and D-mannitol.

\begin{tabular}{|c|c|c|c|c|c|}
\hline \multirow[t]{2}{*}{ Character } & \multicolumn{3}{|c|}{ B. thermacidophilum } & \multirow{2}{*}{$\begin{array}{l}\text { B. thermophilum } \\
\text { JCM } 1207^{\mathrm{T}}\end{array}$} & \multirow[t]{2}{*}{ B. boum* } \\
\hline & 35 & 36 & 37 & & \\
\hline \multicolumn{6}{|l|}{ Acid from: } \\
\hline D-Gluconate & - & W & $\mathrm{W}$ & - & - \\
\hline D-Ribose & + & - & W & - & - \\
\hline L-Arabinose & + & + & w & - & - \\
\hline D-Xylose & + & - & - & - & - \\
\hline D-Rhamnose & - & - & - & & \\
\hline D-Trehalose & - & - & - & $\mathrm{d}$ & - \\
\hline D-Sorbitol & + & + & + & - & - \\
\hline D-Sorbose & - & - & - & & \\
\hline Lactose & + & - & - & d & $\mathrm{d}$ \\
\hline Melezitose & - & + & + & $\mathrm{d}$ & - \\
\hline Inulin & - & - & - & $\mathrm{d}$ & + \\
\hline Starch & - & + & + & + & + \\
\hline Salicin & + & - & - & $\mathrm{d}$ & - \\
\hline \multicolumn{6}{|l|}{ Growth at: } \\
\hline Maximum temp. $\left({ }^{\circ} \mathrm{C}\right)$ & $48 \cdot 5$ & $49 \cdot 5$ & $49 \cdot 5$ & $47 \cdot 5$ & 45 \\
\hline Minimum pH & $4 \cdot 0$ & $4 \cdot 0$ & $4 \cdot 0$ & $4 \cdot 2$ & $>5 \cdot 0$ \\
\hline $\mathrm{G}+\mathrm{C}$ content $(\mathrm{mol} \%)$ & $55 \cdot 4$ & $57 \cdot 7$ & $58 \cdot 3$ & $60 \cdot 0$ & $60 \cdot 0$ \\
\hline
\end{tabular}

* From Scardovi et al. (1979). 
Table 3. Comparison of percentage DNA relatedness levels between some known Bifidobacterium species, determined using DNA reassociation rates and membrane hybridization

\begin{tabular}{|c|c|c|}
\hline Species tested & $\begin{array}{l}\text { DNA reassociation } \\
\text { rate }(\%)^{*}\end{array}$ & $\begin{array}{c}\text { Membrane } \\
\text { hybridization }(\%) \dagger\end{array}$ \\
\hline B. pseudolongum JCM $1205^{\mathrm{T}} \times$ B. globosum $\mathrm{JCM} 5820^{\mathrm{T}}$ & $78 \cdot 4$ & $76 \cdot 0-80 \cdot 0$ \\
\hline B. dentium JCM $1195^{\mathrm{T}} \times$ B. adolescentis JCM $1275^{\mathrm{T}}$ & $61 \cdot 2$ & $50 \cdot 0-59 \cdot 0$ \\
\hline B. adolescentis $\mathrm{JCM} 1275^{\mathrm{T}} \times$ B. infantis $\mathrm{JCM} 1222^{\mathrm{T}}$ & $34 \cdot 1$ & $36 \cdot 0$ \\
\hline B. infantis $\mathrm{JCM} 1222^{\mathrm{T}} \times$ B. thermophilum $\mathrm{JCM} 1207^{\mathrm{T}}$ & $38 \cdot 0$ & $23 \cdot 0$ \\
\hline B. infantis $\mathrm{JCM} 1222^{\mathrm{T}} \times$ B. infantis $\mathrm{JCM} 1220$ & $101 \cdot 9$ & - \\
\hline
\end{tabular}

* Results from this study.

$\dagger$ Results from Lauer \& Kandler (1983).

DNA homologies (ranging from 87.0 to $108 \%$ ) within the new group indicated that they were a homogeneous genetic group, although strain 35 was a little distant. However, the levels of DNA relatedness between the new strain and all of the existing Bifidobacterium species ranged from 0 to $58.9 \%$. This is obviously lower than the species-defining border $(70 \%$ DNA homology), hence a new species of Bifidobacterium should be defined. The highest DNA reassociation value was measured between the new strain and $B$. thermophilum, indicating a closer relationship between these two strains. A possible explanation for this is their shared thermophilic characteristic.

To test the reliability of the liquid reassociation-rate method we used, DNA-DNA homologies between some of the reference strains were measured. Table 3 shows that the DNA-DNA reassociation rates obtained by us were in accordance with those obtained by membrane hybridization (Lauer \& Kandler, 1983).

\section{Phylogenetic position of Bifidobacterium thermacidophilum sp. nov.}

The complete 16S rDNA of Bifidobacterium thermacidophilum sp. nov. (1533 bp) was sequenced and compared with sequences from 20 type species of Bifidobacterium and that of the type strain of Gardnerella vaginalis. On the basis of the 16S rDNA sequences in a consensus length of $1438 \mathrm{bp}$, the similarity levels were analysed and a phylogenetic tree rooted with $G$. vaginalis was constructed (Fig. 2). The results indicated that $B$. thermacidophilum was relatively close to $B$. thermophilum ( $92.70 \%$ similarity), and both formed a distinct phylum relative to other Bifidobacterium species.

As the new species was related to $B$. thermophilum, both phylogenetically and genetically, some of their phenotypic characteristics were compared. According to Scardovi (1986), B. thermophilum and B. boum were closely related, so the latter species was also included for comparison. Table 2 shows that B. thermacidophilum fermented pentoses such as arabinose, ribose and sorbitol, unlike B. thermophilum and B. boum. The

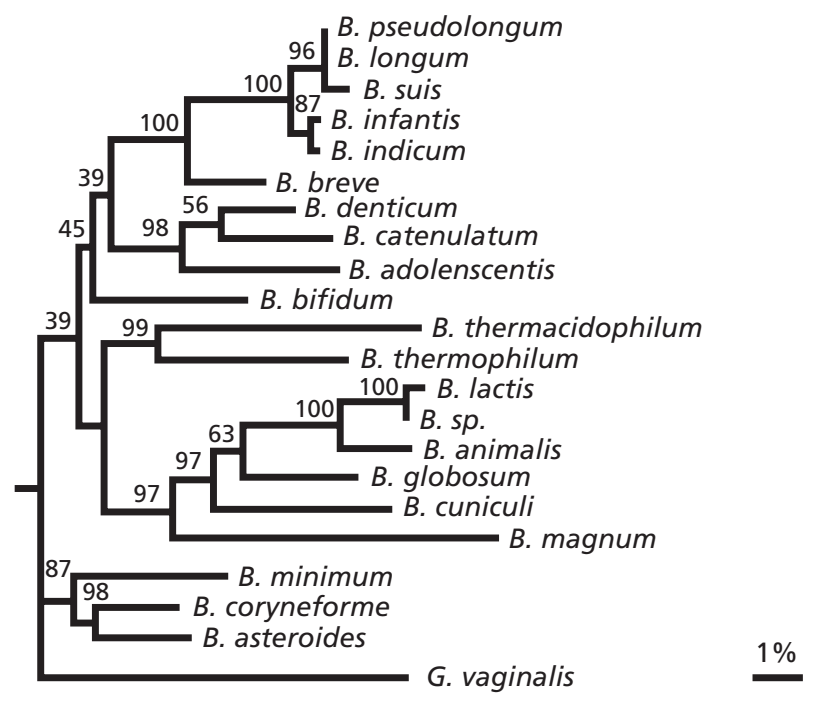

Fig. 2. Dendrogram based on $16 \mathrm{~s}$ rDNA sequences in a consensus length of $1438 \mathrm{bp}$, indicating the phylogenetic relationship of Bifidobacterium thermacidophilum 36 and 20 existing Bifidobacterium spp. The tree was rooted with Gardnerella vaginalis and constructed by using the Fitch method. The bootstrap values were calculated from 100 trees. The number at each branch point represents percentage bootstrap support. Bar, $1 \%$ sequence divergence.

new species also survived better in unfavourable environmental conditions such as elevated temperatures as high as $49 \cdot 5^{\circ} \mathrm{C}$ and low $\mathrm{pH}$.

The phylogenetic analysis in this study showed unreasonably high similarities $(\geqslant 97.7 \%)$ between the 16S rRNA sequences of Bifidobacterium pseudolongum ATCC $25526^{\mathrm{T}}$ and Bifidobacterium longum ATCC $15707^{\mathrm{T}}$ and those of Bifidobacterium indicum ATCC $25912^{\mathrm{T}}$ and Bifidobacterium infantis ATCC $15697^{\mathrm{T}}$, respectively. However, the two pairs of species were demonstrated to be distantly related by DNA-DNA relatedness (Lauer \& Kandler, 1983). A recent study (Miyake et al., 1998) indicated that the disparity between phylogenetic and DNA-DNA relatedness analyses of these strains was caused by the incorrectly 
registered sequences of B. pseudolongum ATCC $25526^{\mathrm{T}}$ (M58742) and B. indicum ATCC $25912^{\mathrm{T}}$ (M58737) in the databases. Phylogenetic analysis based on the reregistered sequences (D86187 and D86188) of the two strains showed that B. pseudolongum ATCC $25526^{\mathrm{T}}$ and B. indicum ATCC $25912^{\mathrm{T}}$ were close to Bifidobacterium globosum and Bifidobacterium coryneforme, respectively. Because the new sequences have not appeared in EMBL/GenBank/DDBJ thus far, the two old sequences had to be used for phylogenetic tree construction in this study.

\section{Description of Bifidobacterium thermacidophilum sp. nov.}

Bifidobacterium thermacidophilum (therm.ac.id.o' phil. um. Gr. n. therme heat; M.L. n. acidum acid; Gr. adj. philus loving; M.L. adj. thermacidophilum heat/ acid-loving).

Gram-positive, non-motile, non-sporing irregular rods, arranged singly or occasionally in a ' $\mathrm{V}$ ' shape, are $0.5 \times 1.5-2.5 \mu \mathrm{m}$ in size after $16-24 \mathrm{~h}$ in TPYG liquid at $37^{\circ} \mathrm{C}$. Liquid cultures of some strains can form a homogenous sediment, but it is readily dispersed by shaking. Anaerobic growth also occurs in standing culture under $90 \%$ air plus $10 \% \mathrm{CO}_{2}$. Colonies on TPYG agar are circular, convex with entire edges, white and reach $1.5-2 \mathrm{~mm}$ in diameter after $24 \mathrm{~h}$ cultivation. The optimum temperature for growth is $37-41{ }^{\circ} \mathrm{C}$ while the temperature range for growth is $30-49.5^{\circ} \mathrm{C}$. The optimum initial $\mathrm{pH}$ is $7 \cdot 0-7 \cdot 2$; growth at $\mathrm{pH} 4.5$ is quite good but is delayed at $\mathrm{pH}$ 4.0. Fructose, galactose, arabinose, sorbitol, melibiose, sucrose, raffinose, melezitose and starch are fermented. Mannose, mannitol, rhamnose, trehalose, sorbose and inulin are not fermented. Fermentation of gluconate, ribose, xylose, lactose and salicin is variable. Catalase is negative. Gelatin is not liquefied. $\mathrm{H}_{2} \mathrm{~S}$ is not produced. Litmus milk is not acidified and coagulated by most of the strains. The fermentation products from glucose are acetic and lactic acid at a molar ratio of $2 \cdot 46-2 \cdot 72: 1$. Final $\mathrm{pH}$ values of 3.6 can be reached. The $\mathrm{G}+\mathrm{C}$ content of the DNA is $56.85 \pm 2.05 \mathrm{~mol} \%$ ( $57.7 \mathrm{~mol} \%$ for the type strain). The micro-organism was found in the waste water of a bean-curd farm in Beijing. The type strain (strain 36) has been deposited in China General Microbiological Culture Collection Center (CGMCC) (Beijing) as deposition AS 1.2282 .

\section{ACKNOWLEDGEMENTS}

This study was supported by the grants from the China National Foundation of Sciences and the Chinese Academy of Sciences. We appreciate the help of Professor Karel Kersters in reviewing this manuscript and for valuable advice, and the assistance of Dr A. J. M. Stams in correcting the English.

\section{REFERENCES}

Biavati, B. \& Mattarelli, P. (1991). Bifidobacterium ruminantium sp. nov. and Bifidobacterium merycicum sp. nov. from the rumens of cattle. Int J Syst Bacteriol 41, 163-168.
Biavati, B., Mattarelli, P. \& Crociani, F. (1991). Bifidobacterium saeculare: a new species isolated from feces of rabbit. Syst Appl Microbiol 14, 389-392.

Chevalier, P., Roy, D. \& Ward, P. (1990). Detection of Bifidobacterium species by enzymatic methods. J Appl Bacteriol 68, 619-624.

Crociani, F., Biavati, B., Alessandrini, A., Chiarini, C. \& Scardovi, V. (1996). Bifidobacterium inopinatum sp. nov. and Bifidobacterium denticolens sp. nov., two new species isolated from human dental caries. Int J Syst Bacteriol 46, 564-571.

De Ley, J., Cattoir, H. \& Reynacrits, A. (1970). The quantitative measurement of DNA hybridization from renaturation rates. Eur J Biochem 12, 133-142.

Felsenstein, J. (1993). PHYLIP (Phylogeny Inference Package), version 3.5. Department of Genetics, University of Washington, Seattle, USA.

Harrison, J., Molloy, P. L. \& Clark, S. J. (1994). Direct cloning of polymerase chain reaction products in an Xcml T-vector. Anal Biochem 216, 235-236.

Holdeman, L. V., Cato, E. P. \& Moore, W. E. C. (1977). Anaerobic Laboratory Manual, 4th edn. Blacksburg, VA: Virginia Polytechnic Institute and State University.

Kaufmann, P., Pfefferkorn, A., Teuber, M. \& Meile, L. (1997). Identification and quantification of Bifidobacterium species isolated from food with genus-specific 16S rRNA-targeted probes by colony hybridization and PCR. Appl Environ Microbiol 63, 1268-1273.

Lauer, E. (1990). Bifidobacterium gallicum sp. nov. isolated from human faeces. Int J Syst Bacteriol 40, 100-102.

Lauer, E. \& Kandler, O. (1983). DNA-DNA homology, murein types and enzyme patterns in the type strains of the genus Bifidobacterium. Syst Appl Microbiol 4, 42-64.

Leblond-Bourget, N., Philippe, H., Mangin, I. \& Decaris, B. (1996). $16 \mathrm{~S}$ rRNA and $16 \mathrm{~S}$ to $23 \mathrm{~S}$ internal transcribed spacer sequence analyses reveal inter- and intraspecific Bifidobacterium phylogeny. Int J Syst Bacteriol 46, 102-111.

Ling, D., Zhou, Y. \& Yuan, Q. (1996). Numerical analysis and determinative tests for bifidobacteria of human and animal origin. In Germfree Life and its Ramifications, vol. XII, pp. 123-128. Edited by K. Hashimoto, B. Sakakibara, S. Tazume \& K. Shimizu. Shiozawa: ISG Publishing Committee.

Marmur, J. (1961). A procedure for the isolation of deoxyribonucleic acid from microorganisms. J Mol Biol 3, 208-218.

Marmur, J. \& Doty, P. (1962). Determination of the base composition of deoxyribonucleic acid from its thermal denaturation temperature. $J$ Mol Biol 5, 109-118.

Meile, L., Ludwig, W., Rueger, U., Gut, C., Kaufmann, P., Dasen, G., Wenger, S. \& Teuber, M. (1997). Bifidobacterium lactis sp. nov., a moderately oxygen tolerant species isolated from fermented milk. Syst Appl Microbiol 20, 57-64.

Miyake, T., Watanabe, K., Watanabe, T. \& Oyaizu, H. (1998). Phylogenetic analysis of the genus Bifidobacterium and related genera based on 16S rDNA sequences. Microbiol Immunol 42, 661-667.

Sambrook, J., Fritsch, E. F. \& Maniatis, T. (1989). Molecular Cloning : a Laboratory Manual, 2nd edn. Cold Spring Harbor, NY : Cold Spring Harbor Laboratory.

Scardovi, V. (1986). Genus Bifidobacterium Orla-Jensen. In Bergey's Manual of Systematic Bacteriology, vol. 2, pp. 14181434. Edited by P. H. A. Sneath, N. S. Mair, M. E. Sharpe \& J. G. Holt. Baltimore: Williams \& Wilkins. 
Scardovi, V., Trovatelli, L. D., Biavat, B. \& Zani, G. (1979). Bifidobacterium cuniculi, Bifidobacterium choerinum, Bifidobacterium boum, and Bifidobacterium pseduocatanulatum; four new species and their deoxyribonucleic acid homology relationships. Int J Syst Bacteriol 29, 291-311.

Stackebrandt, E. \& Goebel, B. M. (1994). Taxonomic note: a place for DNA-DNA reassociation and 16S rRNA sequence analysis in the present species definition in bacteriology. Int $J$ Syst Bacteriol 44, 846-849.

Watabe, J., Benno, Y. \& Mitsuoka, T. (1983). Bifidobacterium gallinarum sp. nov.: a new species isolated from the ceca of chickens. Int J Syst Bacteriol 33, 127-132. 